\title{
Cellular Lipid Comparisons Between Strains of Treponema hyodysenteriae and Treponema innocens
}

\author{
HERBERT M. MATTHEWS ${ }^{1 *}$ AND JOANN M. KINYON ${ }^{2}$ \\ Department of Microbiology and Immunology, University of Arkansas for Medical Sciences, Little Rock, Arkansas $72205^{1}$ \\ and College of Veterinary Medicine, Iowa State University, Ames, Iowa $50011^{2}$
}

\begin{abstract}
The cellular lipids of 11 strains of Treponema hyodysenteriae and 10 strains of non-enteropathogenic, weakly beta-hemolytic spirochetes classified as Treponema innocens were extracted with chloroformmethanol and analyzed by thin-layer and gas-liquid chromatography for fatty acids, alkenyl moieties, alkenyl ether lipid compositions, monoglycosyldiglyceride, acylmonoglycosyldiglyceride, and the types of sugars in the glycolipids. Most strains were distinguishable at the species level on the basis of the ratio of 14:0 to iso-15:0 alkenyl moieties; 14:0 moieties predominated in most $T$. hyodysenteriae strains, whereas most strains classified as $T$. innocens contained more iso-15:0 moieties. The other aspects of lipid composition were not useful for differentiation. All of the strains had similar cellular fatty acid profiles and contained monoglycosyldiglyceride. The mean alkenyl ether lipid compositions were 48 and $32 \%$ of the total lipids of strains of $T$. hyodysenteriae and $T$. innocens, respectively. Galactose was the predominant sugar in the glycolipids of 18 strains, 17 of which also contained acylmonoglycosyldiglyceride. Three strains classified as $T$. innocens contained primarily glucose in their glycolipids and did not contain acylmonoglycosyldiglyceride. Gas-liquid chromatographic determinations of the alkenyl chain profiles of the extractable cellular lipids provided useful information for differentiation of the etiological agent of swine dysentery from morphologically similar, nonpathogenic spirochetes.
\end{abstract}

Mammạlian intestinal tracts contain a large array of anaerobic microorganisms, including spirochetes $(5,7,8,32)$. Treponema hyodysenteriae, the primary etiological agent of swine dysentery (6), and Treponema innocens, a nonpathogenic enteric spirochete of swine (13), are two of the most widely studied of the intestinal spirochetes. The deoxyribonucleic acids of these organisms have guanine-plus-cytosine contents of $25.8 \mathrm{~mol} \%$ and exhibit $28 \%$ homology (28), and the organisms are remarkably similar morphologically and biochemically. An in vivo test for enteropathogenicity (11, $12,14,15)$ is the most definitive test for distinguishing the two species. The most widely used differential in vitro test is simply a test of the degree of beta-hemolysis produced on blood agar; less complete hemolysis is produced by $T$. innocens than by $T$. hyodysenteriae $(13,19)$. Identification on the basis of conventional biochemical characteristics does not appear to be reliable in view of the conflicting results from different laboratories $(13,19,31)$. Enzymatic tests (9) and serological methods in the form of growth inhibition (18) and slide agglutination (3) tests have been reported to be differential.

Fatty acid profiles of cellular lipids $(2,10,16,26,30)$ and sometimes complex lipid compositions (16) are useful in taxonomic placement of bacteria. Phospholipid and glycolipid compositions have been proposed as differential traits of the spirochetal genera Spirochaeta, Treponema, and Leptospira (21). Matthews et al. $(24,25)$ have reported that the lipids of $T$. hyodysenteriae $\mathrm{B} 78^{\mathrm{T}}$ ( $\mathrm{T}=$ type strain) and $T$. innocens $\mathrm{B} 256^{\mathrm{T}}$ differ markedly from each other, as well as from the lipids of other treponemal species.

The objective of this investigation was to examine the lipids of 21 strains previously classified as $T$. hyodysenteriae or $T$. innocens to determine to what extent differences in lipid composition previously reported for the type strains correlate with identification of these species based on enteropathogenicity and the amount of beta-hemolysis produced.

\footnotetext{
* Corresponding author.
}

(A preliminary report of this work has been presented previously [Abstr. Ann. Meet. Am. Soc. Microbiol. 1982, I72, p. 106].)

\section{MATERIALS AND METHODS}

Treponemal strains. A total of 11 strains of $T$. hyodysenteriae (strains B $78^{\mathrm{T}}$ [= ATCC $27164^{\mathrm{T}}$ ], A-1, 9605, Dys-7, B254, B169, B234, B140, B204, JWPM 300/8, and B153), including strains of each of the four serotypes proposed by Baum and Joens (1), and 10 strains classified as $T$. innocens (strains B256 ${ }^{\mathrm{T}}$ [= ATCC $29796^{\mathrm{T}}$ ], Puppy, Dys-676, B6580, B297, B6571, 4/71, 1555a, B359, and B6830) were obtained from the culture collection at Iowa State University by one of us (J.M.K.). The strains of $T$. hyodysenteriae had been classified on the basis of being enteropathogenic for swine or mice or both and on the basis of producing complete betahemolysis on blood agar, whereas nonpathogenic but morphologically similar strains that were weakly beta-hemolytic had been classified as $T$. innocens (11-14; Kinyon, unpublished data).

Growth of organisms. The treponemes were grown at $39^{\circ} \mathrm{C}$ with magnetic stirring bar agitation under an atmosphere of $10 \% \mathrm{CO}_{2}$ in $\mathrm{N}_{2}$ in Trypticase soy broth containing $0.5 \%$ glucose, $3 \%$ fetal calf serum, $0.2 \%$ sodium bicarbonate, and $0.05 \%$ cysteine hydrochloride (17) until the early stationary phase of growth. Cells were collected by filtration with a Pellicon cassette system (Millipore Corp., Bedford, Mass.) and by centrifugation at $12,000 \times g$ for $30 \mathrm{~min}$ at $4^{\circ} \mathrm{C}$. The organisms were washed three times with $20 \mathrm{mM}$ phosphatebuffered saline ( $\mathrm{pH} 7.3)$, lyophilized, and stored at $-20^{\circ} \mathrm{C}$.

Lipid extraction and analyses. Lipids were extracted with chloroform and methanol as previously described (23) and were stored in chloroform-methanol $(19: 1, \mathrm{vol} / \mathrm{vol})$ at $-20^{\circ} \mathrm{C}$. Monoglycosyldiglyceride (MGDG) and acylmonoglycosyldiglyceride (acylMGDG) were isolated and detected by using alpha-naphthol and by charring with sulfuric acid after thinlayer chromatography of the lipid extracts on Silica $\mathrm{Gel} \mathrm{H}$ 
with chloroform-methanol-28\% ammonium hydroxide $(60: 10: 1, \mathrm{vol} / \mathrm{vol})$. Methyl esters of the fatty acids and dimethyl acetals of the alkenyl moieties of the ether lipids were prepared from the lipid extracts by acid methanolysis (23) and, when desired, were separated by thin-layer chromatography using benzene (24) before analysis. The methyl glycosides obtained by acid methanolysis were converted to trimethylsilyl derivatives $(23,24)$ for analysis.

Gas-liquid chromatography was performed with a Hewlett-Packard model 5710A instrument equipped with flame ionization detectors and glass columns $(1.83 \mathrm{~m}$ by $0.2 \mathrm{~cm}$ [inside diameter]). Fatty acid methyl esters and dimethyl acetals were separated at $158^{\circ} \mathrm{C}$ by using $15 \%$ EGSS-X on Gas-Chrom P (100/120 mesh). Trimethylsilyl derivatives of the methyl glycosides were analyzed at $149^{\circ} \mathrm{C}$ by using $3 \%$ SE-30 on Chromosorb W-HP (80/100 mesh).

Lipid constituents were identified and quantified by using authentic reference and internal standards as previously described $(23,24)$ and by comparison with previously characterized lipids and lipid derivatives from the type strains $(24,25)$. The quantities of alkenyl ether lipids in the lipid extracts were estimated from the average chain lengths and the relative amounts of the acyl and alkenyl moieties (24), as determined by gas-liquid chromatography.

\section{RESULTS}

Fatty acid and alkenyl chain profiles. The fatty acid and alkenyl chain profiles of each of the 21 strains classified as $T$. hyodysenteriae or T. innocens were determined after separation of the fatty acids from the alkenyl moieties by thin-layer chromatography (data not shown). The same three or four principal types ( $>99 \%$ of the total) of alkenyl moieties (14:0, iso-15:0, anteiso-15:0, and 16:0 moieties) occurred in each strain. Only the anteiso-15:0 alkenyl moiety cochromatographed with a fatty acid present in the treponemal extracts (14:0 fatty acid). Of the 21 strains, 8 contained the anteiso15:0 alkenyl moiety as a minor component, comprising 5 to $13 \%$ of the total alkenyl chains or less than $2 \%$ of the total acyl and alkenyl chains.

Since the other three major alkenyl components did not cochromatograph with any fatty acid from any of the 21 strains, the profiles of the combined esterified fatty acid and alkenyl moieties were also determined for each strain without prior separation of the two groups by thin-layer chromatography (Table 1). Figure 1 shows chromatograms for one strain typical of most of the strains classified as belonging to each of the two species. Most strains of both species were similar to their respective type strains both as to the types and as to the relative distributions of the acyl and alkenyl chains. Saturated chains comprised at least $96 \%$ of the total chains in all strains. The branched-chain compositions of all strains were similar and ranged from about 16 to $37 \%$ of the total chains, with iso-15:0 fatty acid and alkenyl moieties predominating. The profiles obtained for the type strains were similar to previous results obtained by using different cultural conditions $(24,25)$. Relative decreases in the iso15:0 moiety combined with increases in the 16:0 fatty acid and alkenyl moieties in $T$. innocens $\mathrm{B} 256^{\mathrm{T}}$ compared with previous results $(25)$ were the major differences.

The fatty acid profiles of the 21 strains were similar and could not be used for differentiation. Fatty acids that comprised more than $85 \%$ of the total fatty acids in each strain were the 16:0, iso-15:0, 14:0, and 18:0 fatty acids (in order of decreasing relative amounts). Anteiso-15:0 fatty acid and alkenyl moieties found previously and in this study to be absent in $T$. innocens $\mathrm{B} 256^{\mathrm{T}}$ but present in $T$. hyodysenteriae $B 78^{\mathrm{T}}(24,25)$ were found in 17 of the 21 strains.

Most strains of $T$. hyodysenteriae could be distinguished from the nonpathogenic strains classified as $T$. innocens by the relative amounts (ratio) of the 14:0 and iso-15:0 alkenyl moieties (Table 1), the first two peaks on the chromatograms (Fig. 1). The relative amount of the 14:0 alkenyl moiety was greater in 10 of 11 strains of $T$. hyodysenteriae (ratio of 14:0 moiety to iso-15:0 moiety greater than 1), whereas the iso15:0 alkenyl chain predominated in 8 of 10 strains classified as $T$. innocens (ratio of 14:0 moiety to iso-15:0 moiety less than 1). Of the 21 strains, $2, T$. hyodysenteriae $\mathrm{B} 153$ and $T$. innocens B6830, clearly differed from the other strains classified in the same species with regard to the relative amounts (ratios) of 14:0 and iso-15:0 alkenyl moieties. Two other strains, $T$. hyodysenteriae JWPM $300 / 8$ and $T$. innocens B359, did not clearly fit within either group as these strains had approximately equal amounts of 14:0 and iso-15:0 alkenyl chains. The ratios of 14:0 moieties to iso-15:0 moieties for both strains were less than 1 when the alkenyl chains were analyzed after separation from the fatty acids by thin-layer chromatography, although before separation the ratios were slightly greater than 1 , as shown in Table 1 .

Alkenyl ether lipids. The amounts of alkenyl ether lipids in the 21 strains are shown in Table 2 . A wide range of variation occurred in the strains, but most strains of $T$. hyodysenteriae had greater amounts of the ether lipids than the strains classified as $T$. innocens. The amounts in $T$. hyodysenteriae $\mathrm{B} 78^{\mathrm{T}}$ and B204 were lower than previously reported (25), and this may have been due to the use of different cultural conditions.

Glycolipids. Thin-layer chromatography was used to determine the presence or absence of MGDG and acylMGDG in the 21 strains. These two glycolipids were well separated from each other and from other lipids in the spirochetal extracts by using chloroform-methanol-28\% ammonium hydroxide $(60: 10: 1, \mathrm{vol} / \mathrm{vol})$. The $R_{f}$ values for MGDG and acylMGDG were 0.38 and 0.62 , respectively. The nearest lipids migrating below and above the two glycolipids had $R_{f}$ values of 0.11 and 0.89 , respectively.

All 21 strains of $T$. hyodysenteriae and $T$. innocens contained high levels of MGDG, acylMGDG was present in 10 of the 11 strains of $T$. hyodysenteriae and in 7 of the 10 strains classified as $T$. innocens. acylMGDG was not detected in T. hyodysenteriae Dys-7 or in T. innocens B256 ${ }^{\mathrm{T}}$, B297, and $4 / 71$.

Galactose was the predominant sugar in the glycolipids of 18 of the 21 strains. Of these 18 strains, 11 contained only galactose, whereas glucose comprised 1 to $8 \%$ of the total sugar moieties in 7 strains. Three strains contained glucose as the predominant sugar ( $\geq 97 \%$ of the total sugar); these were the same three strains classified as $T$. innocens which did not contain acylMGDG (strains B256 ${ }^{\mathrm{T}}$, B297, and 4/71).

\section{DISCUSSION}

The hallmark characteristic of $T$. hyodysenteriae is the ability to cause enteric disease, specifically swine dysentery $(13,14) . T$. innocens has been described as similar to $T$. hyodysenteriae but nonpathogenic (13). The inclusion of these non-enteropathogenic spirochetes in a single species has been questioned (19). Until the intraspecies heterogeneity of $T$. innocens is better defined, the question of the validity of this single species designation for the non-enteropathogenic strains will remain unresolved.

Previously, the extractable cellular lipids of type strains $T$. 
TABLE 1. Relative percent compositions of the total fatty acid and alkenyl moieties of the extractable cellular lipids of strains of $T$. hyodysenteriae and non-enteropathogenic weakly beta-hemolytic strains classified as $T$. innocens ${ }^{a}$

\begin{tabular}{|c|c|c|c|c|c|c|c|c|c|c|c|c|}
\hline \multirow[b]{2}{*}{ Strain } & \multicolumn{11}{|c|}{$\%$ Composition } & \multirow[b]{2}{*}{$\begin{array}{c}\text { Ratio of } \\
\text { 14:0 alkenyl } \\
\text { to iso-15:0 } \\
\text { alkenyl }\end{array}$} \\
\hline & $\begin{array}{c}14: 0 \\
\text { Alkenyl }^{b}\end{array}$ & $\begin{array}{l}\text { iso-15:0 } \\
\text { Alkenyl }\end{array}$ & $\begin{array}{c}\text { anteiso-15:0 Alkenyl } \\
\text { plus } 14: 0 \text { fatty acid } \\
\text { or } 14: 0 \text { fatty acid }\end{array}$ & $\begin{array}{l}\text { iso- } \\
15: 0 \\
\text { Fatty } \\
\text { acid }\end{array}$ & $\begin{array}{l}\text { anteiso- } \\
15: 0 \\
\text { Fatty } \\
\text { acid }\end{array}$ & $\begin{array}{l}15: 0 \\
\text { Fatty } \\
\text { acid }\end{array}$ & $\begin{array}{c}16: 0 \\
\text { Alkenyl }\end{array}$ & $\begin{array}{c}16: 0 \\
\text { Fatty } \\
\text { acid }\end{array}$ & $\begin{array}{l}17: 0 \\
\text { Fatty } \\
\text { acid }\end{array}$ & $\begin{array}{c}18: 0 \\
\text { Fatty } \\
\text { acid }\end{array}$ & $\begin{array}{l}18: 1 \\
\text { Fatty } \\
\text { acid }\end{array}$ & \\
\hline \multicolumn{13}{|c|}{ T. hyodysenteriae } \\
\hline$B 78^{\mathrm{T}}$ & 17 & 5 & $11^{d}$ & 10 & 3 & $+^{e}$ & 4 & 45 & + & 2 & + & 3.4 \\
\hline A-1 & 13 & 5 & $9^{f}$ & 10 & + & + & 6 & 54 & + & 2 & 1 & 2.6 \\
\hline 9605 & 12 & 5 & $16^{d}$ & 14 & 3 & + & 3 & 44 & + & 1 & + & 2.4 \\
\hline Dys-7 & 19 & 6 & $13^{f}$ & 11 & 2 & + & 3 & 39 & + & 2 & 3 & 3.2 \\
\hline B254 & 12 & 6 & $10^{f}$ & 12 & 2 & + & 3 & 50 & + & 1 & 1 & 2.0 \\
\hline B169 & 17 & 6 & $13^{f}$ & 14 & 3 & 1 & 1 & 38 & 1 & 2 & + & 2.8 \\
\hline B234 & 17 & 8 & $12^{d}$ & 19 & 2 & + & 2 & 35 & 1 & 2 & + & 2.1 \\
\hline B140 & 13 & 6 & $8^{d}$ & 14 & - & 1 & 3 & 46 & 2 & 4 & 2 & 2.2 \\
\hline B204 & 14 & 6 & $7^{d}$ & 10 & 2 & + & 5 & 51 & + & 2 & 1 & 2.3 \\
\hline JWPM $300 / 8$ & 8 & 6 & $6^{f}$ & 12 & 3 & + & 3 & 53 & 1 & 3 & 4 & 1.3 \\
\hline B153 & 9 & 13 & $7^{d}$ & 17 & 3 & + & 3 & 39 & 1 & 3 & 4 & 0.7 \\
\hline \multicolumn{13}{|l|}{ T. innocens } \\
\hline $\mathrm{B} 256^{\mathrm{T}}$ & 3 & 8 & $5^{d}$ & 23 & - & + & 3 & 53 & 1 & 2 & + & 0.4 \\
\hline Puppy & 5 & 10 & $7^{d}$ & 15 & 3 & + & 2 & 53 & + & 3 & + & 0.5 \\
\hline Dys- 676 & 4 & 8 & $7^{f}$ & 13 & 2 & + & 3 & 58 & + & 2 & + & 0.5 \\
\hline B6580 & 4 & 9 & $6^{f}$ & 14 & 3 & + & 2 & 58 & + & 2 & + & 0.4 \\
\hline B297 & 5 & 8 & $9^{d}$ & 29 & - & 1 & 2 & 41 & 1 & 1 & + & 0.6 \\
\hline B6571 & 4 & 10 & $6^{d}$ & 17 & 2 & + & 2 & 51 & + & 3 & 1 & 0.4 \\
\hline $4 / 71$ & 6 & 9 & $6^{d}$ & 21 & - & + & 3 & 49 & 3 & 2 & 1 & 0.7 \\
\hline $1555 \mathrm{a}$ & 6 & 9 & $6^{d}$ & 12 & 1 & + & 2 & 52 & 2 & 6 & 3 & 0.7 \\
\hline B359 & 10 & 9 & $12^{f}$ & 15 & 2 & + & 2 & 40 & + & 6 & 2 & 1.1 \\
\hline B6830 & 14 & 6 & $13^{d}$ & 14 & 3 & 1 & 3 & 41 & 2 & 1 & + & 2.3 \\
\hline
\end{tabular}

${ }^{a}$ Acid methanolysis of the total chloroform-methanol-extractable cellular lipids was performed. Methyl esters of the fatty acids and dimethyl acetals of the alkenyl moieties from the ether lipids were extracted with petroleum ether and analyzed by gas-liquid chromatography without prior separation of the methyl esters from the dimethyl acetals by thin-layer chromatography.

${ }^{b}$ The number to the left of the colon indicates the number of carbon atoms; the number to the right of the colon indicates the number of double bonds.

${ }^{c}$ Less than $2 \%$ of the total acyl and alkenyl moieties was the anteiso-15:0 alkenyl moiety in each strain.

${ }^{d}$ Amount of 14:0 fatty acid only.

$e+$, Amount less than 1\%; -, not detected. Trace amounts of iso-16:0, iso-17:0, and anteiso-17:0 acyl and alkenyl moieties were also detected in most strains.

${ }^{f}$ Combined amounts of anteiso-15:0 alkenyl and 14:0 fatty acid moieties.

hyodysenteriae $\mathrm{B} 78$ and $T$. innocens $\mathrm{B} 256$ were found to differ primarily in alkenyl chain profiles, amounts of alkenyl ether lipids, and types of glycolipids (25). A total of 21 strains classified on the basis of enteropathogenicity and beta-hemolytic activity were analyzed to determine the usefulness of these differences in lipid composition in differentiating $T$. hyodysenteriae from nonpathogenic, weakly beta-hemolytic isolates considered to be $T$. innocens.

Differences in alkenyl chain profiles, particularly the relative amounts of the 14:0 and iso-15:0 alkenyl moieties, correlated well with enteropathogenicity and beta-hemolytic activity for distinguishing isolates of $T$. hyodysenteriae from isolates of $T$. innocens. Most $T$. hyodysenteriae strains contained more 14:0 alkenyl moiety than iso-15:0 alkenyl moiety, whereas the opposite relationship was true for the majority of $T$. innocens strains. Both species were somewhat heterogeneous in that the alkenyl chain profiles of two strains of each species did not correlate with enteropathogenicity and hemolytic activity as found for the other 17 strains.

Although alkenyl chain profiles are not conclusively differential, they are potentially useful when combined with other tests for identification of $T$. hyodysenteriae and $T$. innocens. The need for in vitro differential tests is apparent from the lack of agreement concerning the value of the relatively limited number of tests which have been proposed.
The only generally accepted, although somewhat subjective, in vitro differential test is the test for the degree of betahemolysis produced on blood agar $(12-14,19)$. Hemolytic activity correlates directly with enteropathogenicity $(13,14)$, except for rare exceptions (3). Kinyon and Harris (13) described the two species as differing in fructose fermentation and indole production. Lemcke and Burrows (19) could not distinguish $T$. hyodysenteriae from other intestinal spirochetes from swine by fructose fermentation; indole production was also found not to be an absolute criterion for differentiation, but these authors believed that it might be helpful when combined with other criteria since all of their 31 strains of $T$. hyodysenteriae produced indole and 19 of 28 weakly beta-hemolytic strains did not (3). Picard et al. (31) found neither trait useful but reported that differentiation was possible by lactose fermentation and isovaleric acid production, which neither Kinyon and Harris (13) nor Lemcke and Burrows (19) found useful. Hunter and Wood (9) reported that enzymatic assays differentiate spirochetal strains associated with swine dysentery from strains that are not related to the disease, but few investigators seem to have used these assays. Serological methods such as slide agglutination (3) and growth inhibition (18) tests have also been reported to be differential, but these require specific antisera that are not widely available.

Differentiation of $T$. hyodysenteriae and $T$. innocens on 

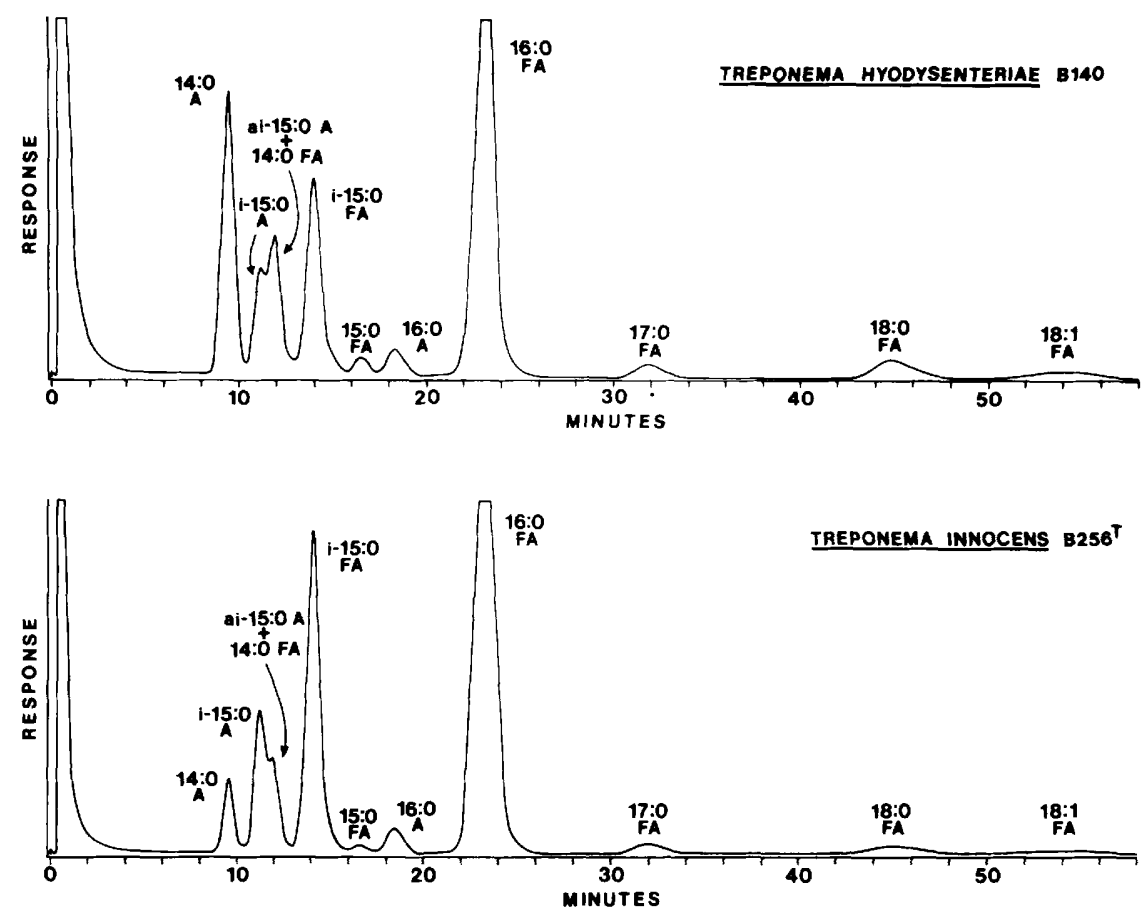

FIG. 1. Gas-liquid chromatograms of esterified fatty acids and alkenyl moieties from the total extractable cellular lipids of $T$ hyodysenteriae $\mathrm{B} 140$ and $T$. innocens $\mathrm{B} 256^{\mathrm{T}}$ as representatives of most strains classified as belonging to the two species (see Table 1 ). Analyses were made on a 15\% EGSS-X column. The number to the left of each colon indicates the number of carbon atoms; the number to the right of each colon indicates the number of double bonds. FA, Fatty acid (methyl ester); A, alkenyl moiety (dimethyl acetal); i, iso branched; ai, anteiso branched.

the basis of alkenyl chain profiles basically involves only two alkenyl chains, the 14:0 and iso-15:0 moieties. These are the first peaks to emerge during gas-liquid chromatography and are separated from other alkenyl peaks, as well as from esterified fatty acids that are also in the treponemal extracts. Therefore, analyses can be performed without a preceding purification procedure using thin-layer chromatography, which is usually required to separate alkenyl moieties from fatty acids before each group is analyzed separately; thus, the analytical process is greatly simplified.

Most treponemes that require serum for growth cannot synthesize fatty acids (21). Fatty acids are incorporated unchanged from the medium into the treponemal lipids; this results in the fatty acid compositions of the spirochetes and the medium being very similar $(21,27)$. In contrast, $T$. hyodysenteriae and $T$. innocens can apparently synthesize fatty acids, as well as alkenyl chains. The fatty acid and alkenyl chain profiles of these organisms are quite unlike the composition of the serum-containing medium $(24,25)$. Therefore, it is unlikely that changes in the medium fatty acid content would affect the ratio of 14:0 to iso-15:0 alkenyl moieties in the two species. However, it is well known and should be remembered that growth conditions can affect the lipid compositions of bacteria, so other changes in cultural or media conditions might influence the alkenyl chain profiles.

Although cellular fatty acid profiles are widely used in bacterial classification $(2,10,16,26,30)$, little use has been made of alkenyl chain profiles for this purpose (29). Since alkenyl ether lipids are widespread among anaerobic bacteria $(4,24)$, alkenyl chain profiles may have wider application as a differential aid among this group of bacteria.

Most strains of $T$. hyodysenteriae contained proportionately more alkenyl ether lipids than found in the $T$. innocens strains. The alkenyl ether lipid compositions are of doubtful differential usefulness but do indicate basic differences in ether lipid metabolism in these two spirochetal species. These kinds of lipids, although common among anaerobic bacteria (4), have been found in small amounts in only one other spirochetal species (27).

We found no correlation between the types of glycolipids present in the 21 strains and other differential criteria. MGDG, which occurs commonly as the major lipid in all Treponema species (21) except Treponema pallidum (23) and in all other members of the Spirochaetales $(20-22,28)$ except Leptospira of the spirochetes examined thus far, was found in all 21 strains. acylMGDG, which had previously been found among spirochetes only in $T$. hyodysenteriae $\mathrm{B} 78^{\mathrm{T}}$ and B204 $(24,25)$, occurred in 17 strains.

Although the types of sugar in the glycolipids of $T$. hyodysenteriae $\mathrm{B} 78^{\mathrm{T}}$ and $T$. innocens $\mathrm{B} 256^{\mathrm{T}}$ differ $(24,25)$, this was not generally true for other strains of the two species. Spirochetal glycolipids usually contain galactose as the only sugar moiety, or galactose predominates in combination with glucose (21). This was also true of 18 of the 21 strains examined in this study. Only three strains considered to be $T$. innocens contained glycolipids with only glucose, a trait shared with some Spirochaeta species (21).

In summary, our data indicate that alkenyl chain profiles, specifically the ratio of 14:0 to iso-15:0 alkenyl moieties, can be used as an aid in the identification of $T$. hyodysenteriae and $T$. innocens. These profiles are not an absolute criterion but can be used in conjunction with other tests. The close taxonomic relationship of the two species was emphasized by the consistent similarities in the cellular fatty acid profiles of the 21 strains examined. Although all strains had relatively large amounts of alkenyl ether lipids, a trait not shared 
TABLE 2. Proportions of the lipids of strains of $T$. hyodysenteriae and non-enteropathogenic, weakly beta-hemolytic strains classified as $T$. innocens in the alkenyl ether form ${ }^{a}$

\begin{tabular}{|c|c|}
\hline Strain & $\begin{array}{l}\% \text { Of lipids in the } \\
\text { alkenyl ether form }\end{array}$ \\
\hline \multicolumn{2}{|l|}{ T. hyodysenteriae } \\
\hline B $78^{\mathrm{T}} \ldots \ldots \ldots$ & 48 \\
\hline $\mathrm{A}-1 \ldots \ldots \ldots \ldots \ldots \ldots \ldots \ldots \ldots \ldots \ldots \ldots \ldots \ldots$ & 43 \\
\hline $9605 \ldots \ldots \ldots \ldots \ldots \ldots \ldots \ldots \ldots \ldots \ldots \ldots$ & 51 \\
\hline Dys $-7 \ldots \ldots \ldots \ldots \ldots \ldots \ldots \ldots \ldots \ldots \ldots$ & 57 \\
\hline 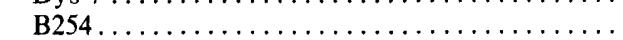 & 48 \\
\hline 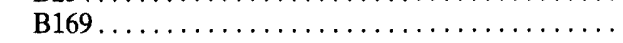 & 47 \\
\hline (2) & 60 \\
\hline 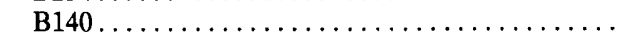 & 44 \\
\hline 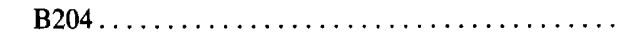 & 41 \\
\hline JWPM $300 / 8 \ldots \ldots \ldots \ldots \ldots \ldots \ldots \ldots \ldots$ & 30 \\
\hline 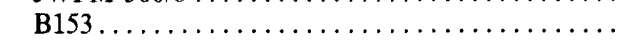 & 54 \\
\hline \multicolumn{2}{|l|}{ T. innocens } \\
\hline $\mathrm{B} 256^{\mathrm{T}} \ldots$ & 21 \\
\hline$\ldots \ldots \ldots \ldots \ldots, \ldots, \ldots, \ldots$, & 32 \\
\hline $\ldots \ldots \ldots \ldots \ldots \ldots \ldots \ldots \ldots \ldots \ldots$ & 26 \\
\hline 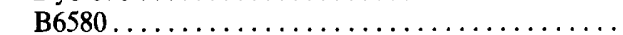 & 31 \\
\hline$\ldots \ldots \ldots \ldots, \ldots \ldots \ldots \ldots \ldots \ldots$ & 30 \\
\hline & 33 \\
\hline 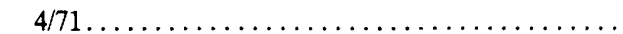 & 36 \\
\hline $1555 a \ldots \ldots \ldots \ldots \ldots \ldots \ldots \ldots \ldots$ & 24 \\
\hline$\ldots \ldots \ldots \ldots \ldots \ldots \ldots \ldots \ldots$ & 39 \\
\hline 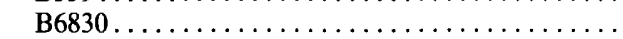 & 44 \\
\hline
\end{tabular}

${ }^{a}$ Percentages represent the moles of the alkenylacyl forms of the lipids per $100 \mathrm{~mol}$ of total diacyl and alkenylacyl forms, as calculated from the molar ratios of the total alkenyl moieties to the total fatty acids determined by gas-liquid chromatography.

${ }^{b}$ For $T$. hyodysenteriae the mean \pm standard deviation was $48 \pm$ $8 \%$; for $T$. innocens the mean \pm standard deviation was $32 \pm 7 \%$. Note that for 10 of $11 T$. hyodysenteriae strains the values were $\geq 41 \%$, whereas for 9 of $10 \mathrm{~T}$. innocens strains the values were $\leq 39 \%$.

with other spirochetes that have been investigated, $T$. hyodysenteriae strains tended to have greater amounts than $T$. innocens strains. The glycolipid compositions of most strains were also similar and consisted of MGDG and acylMGDG with galactose as the predominant sugar moiety. However, three strains of $T$. innocens, including the type strain, contained MGDG with glucose predominating and did not contain acylMGDG.

\section{ACKNOWLEDGMENTS}

This research was supported in part by Public Health Service Biomedical General Research Support Grant 5S07RR5350 from the National Institutes of Health.

We thank Alison B. Jester for excellent secretarial assistance in preparation of the manuscript and Susan E. Yohn and Iona T. Hegland for technical assistance in growth of the isolates.

\section{LITERATURE CITED}

1. Baum, D. H., and L. A. Joens. 1979. Serotypes of beta-hemolytic Treponema hyodysenteriae. Infect. Immun. 25:792-796.

2. Braunthal, S. D., S. C. Holt, A. C. R. Tanner, and S. S. Socransky. 1980. Cellular fatty acid composition of Actinobacillus actinomycetemcomitans and Haemophilus aphrophilus. J. Clin. Microbiol. 11:625-630.

3. Burrows, M. R., and R. M. Lemcke. 1981. Identification of Treponema hyodysenteriae by a rapid slide agglutination test. Vet. Rec. 108:187-189.

4. Goldfine, H., and P.-O. Hagen. 1972. Bacterial plasmalogens, p. 329-350. In F. Synder (ed.), Ether lipids, chemistry and biology. Academic Press, Inc., New York.
5. Hanson, A. W. 1970 . Isolation of spirochaetes from primates and other mammalian species. Br. J. Vener. Dis. 46:303-306.

6. Harris, D. L., R. D. Glock, C. R. Christensen, and J. M. Kinyon. 1972. Swine dysentery. I. Inoculation of pigs with Treponema hyodysenteriae (new species) and reproduction of the disease. Vet. Med. Small Anim. Clin. 67:61-64.

7. Harris, D. L., and J. M. Kinyon. 1974. Significance of anaerobic spirochetes in the intestines of animals. Am. J. Clin. Nutr. 27:1297-1304.

8. Hovind-Hougen, K., A. Birch-Andersen, R. Hemik-Nielsen, M. Orholm, J. O. Pedersen, P. S. Teglbjaerg, and E. H. Thaysen. 1982. Intestinal spirochetosis: morphological characterization and cultivation of the spirochete Brachyspira aalborgi gen. nov., sp. nov. J. Clin. Microbiol. 16:1127-1136.

9. Hunter, D., and T. Wood. 1979. An evaluation of the API ZYM system as a means of classifying spirochaetes associated with swine dysentery. Vet. Rec. 104:383-384.

10. Jantzen, E., and J. Lassen. 1980. Characterization of Yersinia species by analysis of whole-cell fatty acids. Int. J. Syst. Bacteriol. 30:421-428.

11. Joens, L. A., and R. D. Glock. 1979. Experimental infection in mice with Treponema hyodysenteriae. Infect. Immun. 25:757760.

12. Joens, L. A., R. D. Glock, and J. M. Kinyon. 1980. Differentiation of Treponema hyodysenteriae from $T$. innocens by enteropathogenicity testing in the CF1 mouse. Vet. Rec. 107:527-529.

13. Kinyon, J. M., and D. L. Harris. 1979. Treponema innocens, a new species of intestinal bacteria, and emended description of the type strain of Treponema hyodysenteriae Harris et al. Int. J. Syst. Bacteriol. 29:102-109.

14. Kinyon, J. M., D. L. Harris, and R. D. Glock. 1977. Enteropathogenicity of various isolates of Treponema hyodysenteriae. Infect. Immun. 15:638-646.

15. Knoop, F. C. 1979. Experimental infection of rabbit ligated ileal loops with Treponema hyodysenteriae. Infect. Immun. 26:11961201.

16. Lechevalier, M. P. 1977. Lipids in bacterial taxonomy-a taxonomist's view. Crit. Rev. Microbiol. 5:109-210.

17. Lemcke, R. M., J. Bew, M. R. Burrows, and R. J. Lysons. 1979. The growth of Treponema hyodysenteriae and other porcine intestinal spirochaetes in a liquid medium. Res. Vet. Sci. 26:315-319.

18. Lemcke, R. M., and M. R. Burrows. 1979. A disc growthinhibition test for differentiating Treponema hyodysenteriae from other intestinal spirochaetes. Vet. Rec. 104:548-551.

19. Lemcke, R., and M. R. Burrows. 1981. A comparative study of spirochaetes from the porcine alimentary tract. J. Hyg. 86:173182.

20. Livermore, B. P., R. F. Bey, and R. C. Johnson. 1978. Lipid metabolism of Borrelia hermsi. Infect. Immun. 20:215-220.

21. Livermore, B. P., and R. C. Johnson. 1974. Lipids of the Spirochaetales: comparison of the lipids of several members of the genera Spirochaeta, Treponema, and Leptospira. J. Bacteriol. 120:1268-1273.

22. Livermore, B. P., and R. C. Johnson. 1975. The lipids of four unusual non-pathogenic host-associated spirochetes. Can. J. Microbiol. 21:1877-1880.

23. Matthews, H. M., T.-K. Yang, and H. M. Jenkin. 1979. Unique lipid composition of Treponema pallidum (Nichols virulent strain). Infect. Immun. 24:713-719.

24. Matthews, H. M., T.-K. Yang, and H. M. Jenkin. 1980. Alk-lenyl ether phospholipids (plasmalogens) and glycolipids of Treponema hyodysenteriae. Analysis of acyl and alk-l-enyl moieties. Biochim. Biophys. Acta 618:273-281.

25. Matthews, H. M., T.-K. Yang, and H. M. Jenkin. 1980. Treponema innocens lipids and further description of an unusual galactolipid of Treponema hyodysenteriae. J. Bacteriol. 143:1151-1155.

26. Mayberry, W. R., D. W. Lambe, Jr., and K. P. Ferguson. 1982 Identification of Bacteroides species by cellular fatty acid profiles. Int. J. Syst. Bacteriol. 32:21-27.

27. Meyer, H., and F. Meyer. 1971. Lipid metabolism in the parasitic and free-living spirochetes Treponema pallidum (Rei- 
ter) and Treponema zuelzerae. Biochim. Biophys. Acta 231:93106.

28. Miao, R. M., A. H. Fieldsteel, and D. L. Harris. 1978. Genetics of Treponema: characterization of Treponema hyodysenteriae and its relationship to Treponema pallidum. Infect. Immun. 22:736-739.

29. Miyagawa, E. 1982. Cellular fatty acid and fatty aldehyde composition of rumen bacteria. J. Gen. Appl. Microbiol. 28:389-408.

30. Moss, C. W. 1978. New methodology for the identification of nonfermenters: gas-liquid chromatographic chemotaxonomy, $\mathrm{p}$. 171-201. In G. L. Gilardi (ed.), Glucose nonfermenting gramnegative bacteria in clinical microbiology. CRC Press, West Palm Beach, Fla.

31. Picard, B., S. Lariviere, and S. A. Saheb. 1980. Comparative study of the biochemical characteristics of hemolytic treponemes isolated from pigs. Can J. Microbiol. 26:985-991.

32. Turek, J. J., and R. C. Meyer. 1977. Studies on a canine intestinal spirochete. I. Its isolation, cultivation and ultrastructure. Can. J. Comp. Med. 41:332-337. 